\begin{tabular}{|c|c|c|}
\hline \multirow{2}{*}{ DVल } & $\begin{array}{l}\text { International Journal of Current Research in } \\
\text { Biosciences and Plant Biology }\end{array}$ & $=$ \\
\hline & Volume $4 \bullet$ Number 1 (January-2017) • ISSN: 2349-8080 (Online) & \\
\hline $\begin{array}{l}\text { EXCELLENT } \\
\text { PUBLISHERS } \\
\end{array}$ & Journal homepage: www.ijcrbp.com & wwwijectrp, com \\
\hline
\end{tabular}

\title{
Diversity of Wild Nutrimental Fruits of District Bahraich, Uttar Pradesh, India
}

\author{
T.P. Mall* and S.C. Tripathi \\ Postgraduate Department of Botany, Kisan P.G. College, Bahraich-271 801 (U.P.), India
}

*Corresponding author.

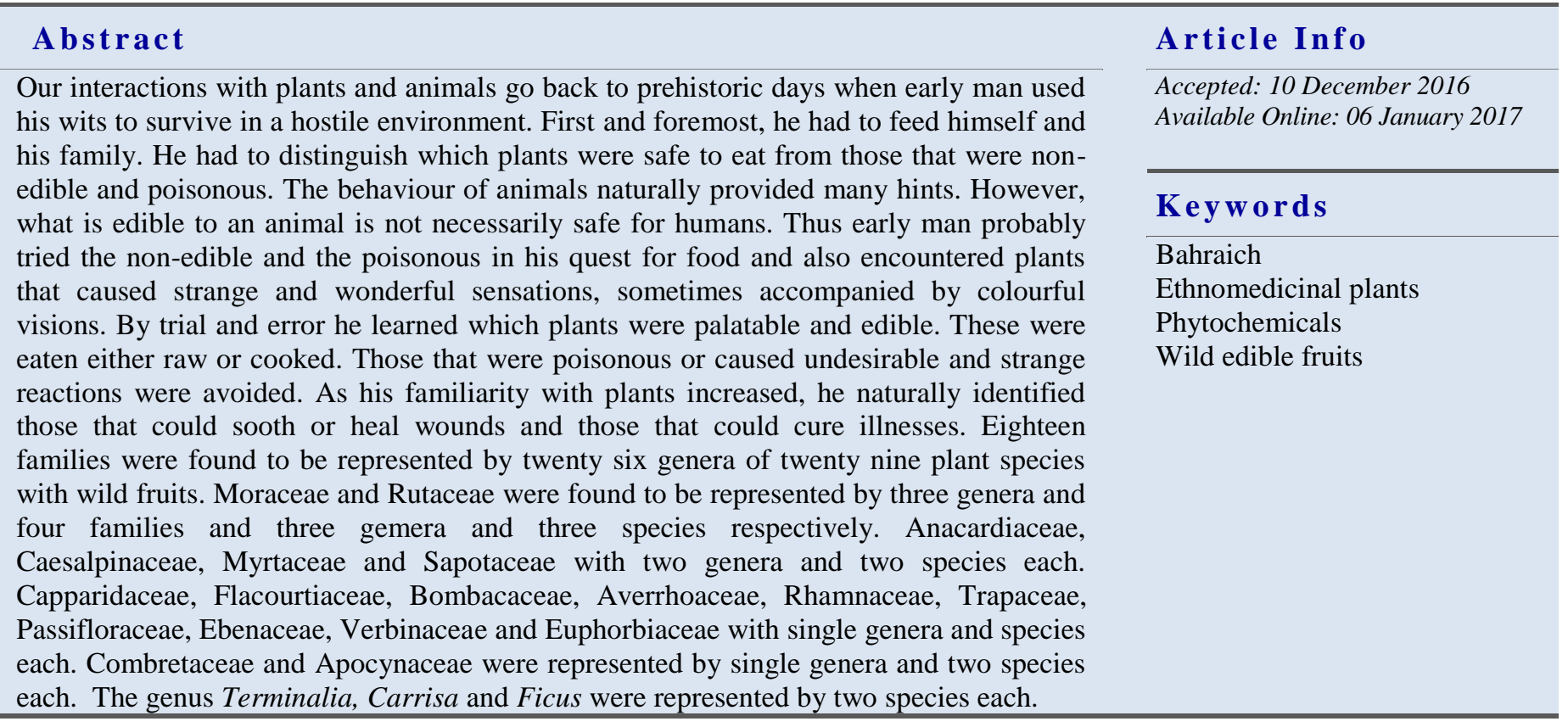

\section{Introduction}

We cannot survive without plants. We depend on plants for food: directly in the form of grains, roots and tubers, fruits, vegetables, spices, oil and beverages. Much of our food also comes indirectly form plants. We get our meat and milk from animals that are dependent on plants for food. Plants provide fuel, either as firewood or in the form of fossil fuel, to cook our food, keep us warm, run our machinery and light up our homes and cities. We also depend on trees for construction materials to build our houses and to craft our furniture. From cotton and flax we get fibres for our clothes. Plant dyes colour our clothes, at least before synthetic dyes were developed. In cities and towns, trees provide shade and shelter, and their flowers brighten the surroundings, Plants in parks and gardens contribute to the serene and peaceful environment, making such places favourite retreats (Chin, 2005). 
The knowledge of utilizing wild plants was painstakingly passed on from generation to generation database of valuable information of the plants around him. It is natural to assume that certain members of the tribe were gradually entrusted with such knowledge. These were variously known as shamans, bomohs, healers or witchdoctors. As communications between settlements was then poor, it is likely that such knowledge developed independently in different locations (Chin, 2005).

The primitive man, through his trial and error, has selected many wild fruits which are edible and subsequently domesticated them which played a very vital part in supplementary diet knowingly or unknowingly. Although due to the ignorance of modern generation the importance of wild plants were recently have been decreasing yet many people specially in rural areas still use them extensively as a supplementary to their basic food requirement. A scientific study of wild fruits is important for the potential sources which are protective foods. The nutrients/pigments present in the fruits prevent different degradative/ageing process in our body and thus via restoring health offer longevity (Singh, 2011). These wild fruits would be utilized at the time of scarcity or cultivated as a source of food material for ever increasing population (Rashid et al., 2008).

India is located to the north of an equator, lies between $8^{\circ} 4^{\prime}$ and $37^{\circ} 6^{\prime}$ north latitude and $68^{\circ} 7^{\prime}$ and $97^{\circ} 25^{\prime}$ east latitude, measures 3214 kilometres from south to north and $2933 \mathrm{~km}$ from east to west, the total land area being $32,87,263$ square kilometres. India is the one of the twenty mega biodiversity countries of the world lying in between Tropic of Capricorn and Tropic of Cancer, has two of the world's eight hottest hot spots out of thirty eight biodiversity hot spots with four in India ie., Western Ghat, North East, Himalaya and Indo Burma. The top mega diversity spots of India is located in the Western Ghats and in the Eastern Himalayas. The Himalaya rise as a virtual wall beyond the snow line, above the alluvial plain lies the Tarai strip, a seasonally marshy zone of sand and clay soil. The Tarai region has higher rain fall than the plains, and downward rushing rivers originating from the Himalaya slow down and spread out in the flatter tarai zone depositing fertile silt and reproductive means during the monsoon season and receding in the dry season. The Tarai, as a result has high water level and is characterized by moist subtropical conditions and a luxuriant turnover of green vegetation all the year around. The climatological and topographical conditions favour the luxuriant growth and development of foliicolous fungi. This North Tarai Region of U. P. is next only to Eastern and Western Ghats, as one of the hottest spots for biodiversity in general and the diversity of fungal organism inhabiting plant in particular offers an ideal opportunity for the morphotaxonomic exploration of the fungal organism, survey and documentation of ethnomedicinal plants due to presence of significant tribal number in side forest villages as well as around the forests. People conserve what they love. They love what they understand and they understand what they are taught. Nature has provided a complete store house of remedies to cure ailments of mankind. About $80 \%$ of the world population depends wholly or partially on traditional medicine for its primary healthcare. Herbal medicines as the major remedy in traditional medical systems have been used in medical practice for thousands of years and have made a great contribution to maintain human health. The plants which are used for medicinal purposes have some chemical constituents or secondary metabolites (which are potential source of drugs) and essential oils of therapeutic importance. The important advantages claimed for therapeutic uses of medicinal plants in various ailments are their safety besides being economical, effective and their easy availability. Keeping the above views in mind, the present study was undertaken for the diversity of wild edible fruits of district Bahraich (U.P.), India.

\section{Materials and methods}

The present study is based on the field survey of Bahraich district of Uttar Pradesh. For the purpose the voucher specimens of ethno-medicinal importance were collected and documented with their ethnotherapeutic data. The information was collected from herbal practitioners or local healers and other experienced persons. They were interviewed for local names, plant part used, method of preparation of medicine, dosages and their mode of administration. The available literature about the plants were also consulted and presented in the enumerations. The specimens were collected, pressed, dried, preserved and mounted as described by Jain and Rao (1976) and identified through the available taxonomic literature, manuals and floras (Hooker, 1897; Duthie, 1994). The specimens were deposited at the Herbarium of the 
Postgraduate Department of Botany, Kisan P.G. College, Bahraich.

\section{Results and discussion}

\section{Capparidaceae:}

\section{Capparis decidua (Forsk) Edgew.}

It is commonly known as 'Ker'. A spreading diffuse thorny shrub. Leaves ovate oblong. Flowers white. Fruits are fleshy berry with ovoid shape. Seeds numerous which remain embedded in pulp. Commonly found on dry places along road sides, railway tracks, river banks, etc. The immature fruits are used for vegetable and picking purposes. They contain glucosinoiates -an acid principle which imparts unpalatability to the ker fruits. After blenching treatment the fruits are made into delicious vegetable. The flower buds are valued as pot herbs. Its ripe fruits are though acrid but they are very well relished (Singh et al., 2013).

All parts of this plant have a number of medicinal properties along with its socioeconomic and ecological benefits. The plant is traditionally used to cure toothache, arthritis, asthma, cough, inflammation, intermittent fevers, malaria, rheumatism and swelling. It is also believed to posses laxative, astringent and vermifuge properties. The alcoholic extract of fruit pulp and root bark is claimed to have anthelmintic activity. The fruits and seeds are used to cure cholera, dysentery and urinary purulent discharges and have diuretic and antidiabetic properties. The spicy taste fruits serve as astringent for bowels, a remedy for bad breath and is claimed to cure cardiac troubles. The seed oil is edible and used to cure skin diseases. It has central nervous system sedative, depressed, anti microbial properties (the water and methanol extract has hepatoprotective properties (Zia-ul-Haq et al., 2011).

The unripe fruits contain protein $14.88 \%$ fat $7.43 \%$, ash $5.96 \%$ crude fibre 12.32 and digestible carbohydrate $59.41 \%$ dry matter. The fruits also contains $5.4 \mathrm{mg}$ beta - carotene, $120 \mathrm{mg}$ ascorbic acid, $90 \mathrm{mg}$ calcium, 179 mg phosphorus, $3.5 \mathrm{mg}$ iron, $1.1 \mathrm{mg}$ copper, $1.6 \mathrm{mg}$ zinc and $1.9 \mathrm{mg}$ manganese $100 \mathrm{~g}$ edible protein respectively (Chauhan et al., 1986). Capparis decidua is traditionally known to provide relief is cold, flu cough and heart disease and as laxative.

\section{Flacourtiaceae:}

Flacourtia jangomas (Lour.) Raeusch., synonyms: Flacourtiac cataphraeta Roxb. Ex willd, Stigmarota jangomas Lour.

It is commonly known as 'Poniyol, Paniyala'._ It is a thorny, small tree. Leaves ovate lanceolate. Flowers yellowish. Fruits globose purple. The ripe fruits are eaten raw. Fruits are stomachic and digestive, allay thirot, useful in biliousness and fever and relieves nausea. Leaves are diaphoretic, astringent and stomachic, good in diarrhoea, piles, weakness of limbs, bleeding gums, toothache and stomatitis, checks purging. Leaves and young shoots are prescribed in diarrhoea. Decoction of the bark is useful in biliousness, bleeding gums and toothache (Yusuf et al., 2009). Bark specially contains tannins, leaves and young shoots are also rich in tannins. Fruits cntain soluble carbohydrates, fats, minerals, ascorbic, tartaric acids, proteins, amino acids and phenolic compounds (Ghani, 2003).

\section{Bombacaceae:}

Bombax ceiba syn. Bombax malabaricum Dc. Salmelia malbarica/ Gossampinus malabrica (Dc) Merr.

Commonly known as Shalmali, Semal, Silk cotton tree. It is a large deciduous tree. Leaves digitate, leaflets 57 , flowers red or yellowish, capsules ovoid. The silk cotton tree is often reffered to as the "silent doctor", for the host of medicinal benefits that is offers almost each part of the tree, including the bark, flowers, fruits, seed and leaves, gums, thorns have therapeutic potential. A herbal composition made from the bark of the tree, for example is administered for the treatment of male sexual and gastro intestinal disorders like dysentery and diarrhoea. The pharmacological benefits are basically due to the presence of Glycosides and tannins in the root and stem. It has haemostatic properties and is administered during menorrhagia. Silk cotton extracts are used in eve care, tentax forte, Achnae pimple cream. The plant is also being used for general debility, diabetes, impotence, spermatorrhoea, urinary stones and liver disorders. However, some of the diseases for example diarrhoea, dysentery, asthma, rheumatism, leprosy, leucorrhoea, body pain, wounds are included in anti-inflammatory, analgesic, anti microbial and oxytocic activities of plant as indirect evidence of scientific validation (Jain and Verma, 2014). 


\section{Averrhoaceae: (Oxalidaceae)}

\section{Averrhoa carambola Linn.}

Commonly known as 'Kamrakh', star fruit in English. The word carambola is derived from the Sanskrit word 'Karmaranga' meaning 'food appetizer'. Averrhoea carambola is a multipurpose, draught resistant evergreen tree. It is gaining lot of importance for its therapeutic potentials. Various part of tree has been used in traditional folklore medicine. It is a good source of potassium, copper, as well as folate and pantothenic acid. The ascorbic acid levels of the star fruit is believed to be responsible for its sweet or sour taste, for a sweet fruit, the ascorbic acid level is around $10.40 \mathrm{mg} / 100 \mathrm{ml}$ of juice. For a sour fruit, the ascorbic acid level is about $15.4 \mathrm{mg} / 100 \mathrm{ml}$ of juice. Due to presence of such nutritive elements the fruit is beneficial in diabetes, also an efficient immune modulator (Manda et al., 2012).

\section{Rutaceae:}

\section{Aegle marmelos Linn. Correa}

Common name Bel, Sirphal. A medium sized deciduous, armed tree. Leaves trifoliate, flowers yellowish - white, fruit large globose. A. marmelos has been reported to contain several phyto constituents mainly marmenol, marmin, marmelosin, marmelide, psoralen, alloimperatorin, rutaretin, scopoletin, aegelin, marmelin, fagarine, anhydromarmelin, limonene, a-phellandrene, betulinic acid, marmesin, impertorin, marmelosin, luvangentin and auropetene (Rahman and Parvin, 2014). Due to the presence of various phyto constituents the plant has antidiarrhoeal, antimicrobial, anticancer, antipyretic, antigenotoxic, antifertility, anti inflammatory antidibetic and diuretic activities.

The essential oil isolated from the leaves of A. marmelos tree has proved to have antifungal activity against animal and human fungi like Trichophyton mentagrophytes, Trichophyton rubrum, Microsporum gypseum, Microsporum audounii, Microsporum cookie, Epidermophyton floccosum, Aspergillus niger, Aspergillus flavus and Histoplasma capsulatum. The leaf extracts and fractions have fungicidal activity against various clinical isolates of dermatophytic fungi. Various extracts of A. marmelos leaves, roots ad fruits have been reported to be active against many bacterial strains. Preclinical studies have shown that A. marmelos leaf extracts were effective in inhibiting the growth of leukemic K 562. Experiments have shown that the phytochemicals such as lupeol, eugenol, cineole and dlimonene present in A. marmelos possess antineoplastic effects. Numerous experimental and epidemiological studies shows that chemoprevention has the potential of providing an important means for cancer prevention. The ethanolic extract, at dose of $200 \mathrm{mg} / \mathrm{kg}$ body weight and $400 \mathrm{mg} / \mathrm{kg}$ body wt. produced significant $(p<0.001)$ reduction in elevated body temperature in a dose dependent manner. This antipyretic effect of extracts was comparable to that of paracetamol $(100 \mathrm{mg} / \mathrm{kg}$ body wt). Anti-ulcer activity of methanol and aqueous extract of $A$. marmelos seeds using indomethacin induced ulceration, stressed induced ulcerations and pylorus ligation induced ulcerations. A. marmelos leaf, seed and fruit is known as affect male fertility in reversible manner. Bark extract is a rich source of marmin and fagrine known for reducing male fertility. Different organic extracts of $A$. marmelos leaves possess highly significant acute and subacute anti- inflammatory activity. In acute and chronic inflammatory animal modes, A. marmelos showed significant anti inflammatory activity and it can be a promising anti inflammatory agent. These activities may be due to the presence of leupeol and skimmianine in the leaves because both the compounds have shown the same potentialities in pure form.

\section{Citrus limon Linn.}

Commonly known as Neembu. It is a small thorny shrub. Leaves ovate, elliptic flowers yellow. Fruits globose. Phenology major parts of the year. Lemons first achieved their healthy claim to fame onboard the ships of early explores to help treat scurvy, a common disease among the sailors. In 1747, James Lind found that lemons and oranges were extremely effective at treated the disease. Which we know was caused by Vitamin C deficiency from months at sea without any fresh produce. Lemons are rarely consumed as a stand-alone fruit due to their intense sour flavour but are extremely popular when used in smaller quantities and in combinations with herbs and spices to lend a wonderful and dynamic flavour to many sauces, salad, dressings, marinades, drinks and desserts. Consuming fruits and vegetables of all kinds has long been associated with reduced risk of many lifestyle related health conditions. According to the American Heart Association eating higher amounts of citrus fruit may lower ischemic stroke risk for women. As an excellent source of the powerful anti oxidant Vitamin C, Lemons and lemon juice can help fight the formation of free radicals known to cause cancer. 
The antioxidant Vitamin $\mathrm{C}$, when eaten in its natural form or applied topically, can help to fight skin damages caused by the sun and pollution, reduce wrinkles and improve overall skin texture. Vitamin $\mathrm{C}$ plays a vital role in the formation of collagen, the support system of skin. The risks for developing asthma are lower in people who consume a high amount of certain nutrients, one of these being Vitamin C. Iron deficiency is one of the common nutrient deficiencies in developed countries and leading cause of anemia. Pairing foods that are high in Vitamin $\mathrm{C}$ with foods that are iron rich will maximize the body's ability to absorb iron. For example, squeeze lemon juice a top salad with spinach and chickpeas. Lemon is a good source of Vitamin $\mathrm{C}$ and other antioxidants which can help the immune system battle germs that cause a cold or flu. Maintaining a healthy diet high in fruits and vegetables is especially important during the winter season when physical activity levels tend to drop. Lemon decreases the risk of obesity, diabetes, heart disease and overall mortality while promoting a healthy complexion, increased energy and overall lower weight.

According to the USDA National Nutrient Database, one raw lemon, without peel (about $58 \mathrm{~g}$ ) provides 17 calories, $0.6 \mathrm{~g}$ of protein, $0.2 \mathrm{~g}$ of fat $5.4 \mathrm{~g}$ of carbohydrate including $1.6 \mathrm{~g}$ of fibre and $1.5 \mathrm{~g}$ of sugar, $51 \%$ daily Vitamin $\mathrm{C}$ needs as well as small amounts of thiamine, rivoflavin, Vitamin B6, pantothenic acid, calcium, iron, magnesium, phosphorus, potassium, copper and manganese.

\section{Rhamnaceae:}

\section{Ziziphus mauritiana Lam.}

Ziziphus mauritiana is an extremely drought hardy and native fruit of India, found wild and cultivated. It is useful as food, fodder, nutrient, medicinal, construction material and fuel. Z. mauritiana is having tremendous medicinal properties, attributed by diverse group of secondary metabolites such as alkaloids, flavonoids, terpenoids, saponin, pectin, triterpenoic acids, and lipids. Jujubosides (saponin) isolated from Ziziphus reported to have haemolytic, sedative, anaxiolytic, and sweetness inhibiting properties. Whereas, cyclopeptide alkaloids, found to have sedative, antimicrobial, hypoglycaemic, anti-plasmodial, anti-infectious, antidiabetic, diuretic, analgesic, anticonvulsant and antiinflammatory activities (Goyal et al., 2012). In spite of the fact that Ziziphus mauritiana having medicinal properties it is neither considered as important medicinal plant nor utilized for medicinal use in main stream therapeutic.

\section{Anacardiaceae:}

\section{Buchanania lanzan Spreng.}

It is commonly known as Chironjee. It is a medium sized deciduous tree, growing to about 50ft tall. It has thick leathery leaves which are broadly oblong. Pyramidal panicles of small bisexual greenish white flowers appear in auxiliary and terminal panicles during early spring. A single panicle bears about 3000-5000 flowers, fruits remain on the tree for quite longer. Fruits are drupe, ovoid or globose, black $8-12 \mathrm{~mm}$ in diameter with hard stones. Unripe fruit are green in colour having single seed.

\section{Ethnomedicinal uses}

Chironzee is regarded for its high value kernel, it is a common substitute of almond amongst dry fruits. Its kernel yield oil. The oil is useful in curing glandular swellings of the neck. Paste of fruit is excellent skin conditioner, gum is useful in treating diarrhoea and rheumatic pain, leaves are used in the treatment of skin diseases. Fruits are used in treating cough and asthma, leaves posses cardiotonic properties, leaf powder or paste is a common cure for wounds.

\section{Phyto-nutrients}

Chironzee fruits as well as kernels are very nutritious. Its fruits contain $74.3 \%$ moisture, $2.2 \%$ protein, $0.8 \%$ fat, $1.5 \%$ fat, $19.5 \%$ carbohydrate, $78 \mathrm{mg} / 100 \mathrm{~g}$ calcium and $28 \mathrm{mg} / 100 \mathrm{~g}$ phosphorus, its calorific value is $49 \mathrm{k}-$ cal $/ 100 \mathrm{~g}$. Its kernels contains moisture $3 \%$, protein $19 \%$, fat $59.1 \%$, carbohydrate $12.1 \%$, mineral matter $3 \%$, fibre $3.8 \%$, calcium $279 \mathrm{mg} / 100 \mathrm{~g}$, phosphorus $528 \mathrm{mg} / 100 \mathrm{~g}$, sulphur $286 \mathrm{mg} / 100 \mathrm{~g}$, iron $8.5 \mathrm{mg} / 100 \mathrm{~g}$, thiamine $0.69 \mathrm{mg} / 100 \mathrm{~g}$, rivoflavin $0.53 \mathrm{mg} / 100 \mathrm{~g}$, niacin $1.5 \mathrm{mg} / 100 \mathrm{~g}$ and Vitamin C $5 \mathrm{mg} / 100 \mathrm{~g}$. The calorific value of kernels is $650 \mathrm{k}-\mathrm{cal} / 100 \mathrm{~g}$. The kernels also contain $34-47 \%$ oil (Gopalan et al., 1984).

\section{Anacardiaceae:}

Spondias pinnata (L.f) Kurz. Synonyms: S. mangifrea Willd., S. acuminata Roxb., Mangifera pinnata L.f.

Commonly known as Amra, deshi Amra, Piala. In 
English wild Mango. This is a medium sized deciduous tree, 9-10.5 $\mathrm{m}$ high, with a pleasant smell. Leaves imparipinnate, crowded at the end of branchlets 30-45 $\mathrm{cm}$ long, leaflets 9-13 pairs, elliptic- oblong, $5-25 \mathrm{~cm}$ long, acuminate, entire. Flowers polygamous, small yellowish-green, fruit a drupe, ovoid $4-5 \mathrm{~cm}$ long greenish- yellow in colour.

\section{Ethnomedicinal uses}

The bark is astringent and refrigerant, infusion of the bark is given in dysentery, diarrhoea, and prevent vomiting. Paste of the bark is used as an embrocation for articular and muscular rheumatism. Decoction of the bark is given in gonorrhoea. Gum of the bark is demulcent. Roots are useful in regulating menstruation. The leaves are appetizing and astringent. Fruit possesses anti scorbutic and astringent properties used in bilious dyspepsia. The unripe fruit is good for rheumatism and sore throat, ripe fruit is tonic, aphrodisiac and astringent to the bowels, cures burning sensation.

\section{Chemical constituents}

Arial parts have been found to contain 2,4-methylene cycloartenone, stigmast-4-en-3-one, $\beta$-sitosterol, glycoside of $\beta$ sitosterol and lignoceric acid. Fruits contain water soluble polysaccharides composed of mainly L-arabinose, D-galactose and galacturonic acid (Ghani, 2003). Presence of $\beta$ - amyrin and oleanolic ancid, glycine, cystine, serine, alanine and leucine have also been detected in the fruits of this plant.

\section{Caesalpiniaceae:}

\section{Bauhinia variegata Linn.}

Commonly known as Kachnar tree, in English Mountain ebony well known ornamental tree. It is small medium size tree growing $10-12 \mathrm{~m}$ height and $50 \mathrm{~cm}$ in diameter. Leaves are long, broad, rounded and bilobed at the base and apex. Flowers are very showy which blom when the leaves start falling. The fruit is pod $15-30 \mathrm{~cm}$ long containing 10-15 seeds.

\section{Ethnomedicinal uses}

In India $B$. variegata has been widely used as a medicinal plant in the tribal, Ayurveda, Unani, and homeopathy systems of medicine. It is believed to possess anti tumour, anti microbial, anti inflammatory, anti goitrogenic, hepatoprotective and heamagglutination properties (Gautam, 2012). The bark is alterative, astringent and tonic is useful in the treatment of skin diseases, scrofula and ulcers. The bark decoction is used for diarrhoea. The overall anti oxidant activity of the plant is due to the presence of flavonoids, phenolic and other phytochemicals which can be a good source of natural antioxidant agent in preventing oxidative stress related degenerative diseases (Gautam, 2012). Paste of leaves and flowers is applied on burn skin twice a day which reduces inflammation as well as cures. The root is used as an antidote to snake poison. A decoction of the root is used to treat dyspepsia. To verify its medicinal potential a lot of study and scientific research has been carried out. The dried buds are used in the treatment of piles, dysentery, diarrhoea and worms.

\section{Phyto-nutrients}

B. variegata is rich in phytochemicals which are responsible for its ethno medicinal properties. It is a good astringent because of the presence of ascorbic acid. The anti oxidant activity can be attributed to flavonoids, phenolic contents. Besides it protein, carbohydrate, various minerals and Vitamins, natural sugar are present in high content.

\section{Tamarindus indica Linn.}

Commonly known as Imli, Ambli in English Tamarind tree. It is a dicotyledonous plant. Green leaves are rich in energy, proteins and minerals. Tamarind fruit pulp has a sweet acidic taste due to a combination of high contents of tartaric acid and reducing sugars. Tamarindus indica is having some reported activities like antidiabetic, hypolipidemic, hepatoprotactive and anti microbial properties (Mehar et al., 2014).

\section{Combretaceae:}

\section{Terminalia bellirica Roxb.}

Popularly known as Beleric, Bahera, Baheda, Bibhitaki. Beleric is a large deciduous tree found throughout India. In areas up to an altitude of 1000 , metres, the tree takes a height of 30 meters, while the bark is brownish grey in colour. The alternate broadly elliptic leaves are clustered towards the end of the branches. They are $10-12 \mathrm{~cm}$ in length and 7-14 $\mathrm{cm}$ in breadth. The simple solitary 
flowers are in auxiliary spikes with offensive odour. They blossom in the month of May. The fruits are ovoid drupes and kernels are sweet but narcotic.

\section{Ethnomedicinal uses}

Terminalia bellirica is a potent ethno medicinal plant used in various ailments like asthma, astringent and anti diarrheal, boost immunity, controls cholesterol, cough, cold, conjunctivitis, diabetes, premature graying of hair, rheumatism, chronic and acute infective conditions, loss of appetite, wounds, etc.

\section{Chemical constituents}

Main chemical constituents which are significant for its medicinal values are sitosterol, gallic acid, ellegic acid, chebulagic acid, galloyl glucose, fatty acid, protein, oxalic acid, tannin, palmitic acid, oleic acid, linoleic acid, galactose, glucose, ethyl gallate (Saraswathi et al., 2012).

\section{Terminalia chebula Retz.}

Commonly known as Harad, Hareda, Haritaki, It is medium sized up to $25 \mathrm{~m}$ tall, deciduous tree, bark dark brown, leaves alternate or opposite, flowers in axillary 5-7 cm long spikes, simple or sometimes branched, about $4 \mathrm{~mm}$ across, yellowish - white and unpleasantly scented, fruit an obovoid or oblong ellipsoid drupe 2.5$5 \mathrm{~cm}$ long, faintly angular, yellow or orange - brown when ripe glaborous.

\section{Ethnomedicinal uses}

In Ayurvedic system of medicine Terminalia chebula is considered as 'King of Medicine' because it is widely used in various ailments. It has antibacterial, antifungal, antiviral, anioxidant, antiaging and antihyperglycemic activities. It is cardio protective, immunomodulator, effective in gastrointestinal disorders and hepatoprotective.

\section{Chemical constituents}

In Terminalia chebula $33 \%$ of the total phytoconstituents are hydrolysable tannins (which may vary from 20-50\%) and are responsible for pharmacological activity. These tannins contain phenolic carboxylic acid like gallic acid, ellagic acid, chebulic acid and gallotannins such as 1,6 di-o-galloyl$\beta$-D- glucose, Ellagitannin such as punacalagin, causranin, corilagin, and terchebulin and others such as chebulanin, neochebulinic acid, chebulagic acid, etc. (Rathinamoorthy and Thilagavthi, 2014).

\section{$\underline{\text { Myrtaceae: }}$}

\section{Psidium guajava Linn.}

It is commonly known as Amrud. In English called as Guava. Guava is a medium sized dicotyledonous evergreen tree, generally 3-10 $\mathrm{m}$ high with many branches. The stems are crooked and the bark is light to redish brown, thin smooth and continuously flaking. Root system is generally superficial and extensive. The leaves are simple and opposite, petiole short the flowers are white, incurved petals, 2-3 in the leaf axils they are fragrant with 4-6 petals and yellow anthers, the fruit is small pear shaped greenish yellow when ripe. The fruit contains several small seeds and consists of a fleshy pericarp and seed cavity with pulp.

\section{Phytochemicals}

Psidium guajava contains broad spectrum of phytochemical including minerals, enzymes, proteins, alcohols and triterpenoide acids, alkaloids, glycosides, steroids, flavonoides, tannins, saponins. Guava is very rich in antioxidants and Vitamins and also high in lutein, zeaxanthine and lycopene. The guava leaves contains several chemical constituents such as limonene, menthol, terpenyl acetate, isopropyl alcohol malic acid, ursolic acid and guayavolic acid essential oil, resins and tannins etc (Shruthi et al., 2013). Nutritional value of guava are often included among super fruits being rich in dietary fiber, Vitamin A and C, folic acid, and dietary minerals, potassium, copper and manganese.

\section{Ethnomedicinal uses}

Psidium guajava is a well known traditional medicinal plant used in various indigenous system of medicine. The leaves and bark of this tree have long history of medicinal uses. It is used as for antiseptic, astringent, anorexia, cerebral ailments, cough, cholera, child birth, convulsions, diarrhoea, dysentery, epilepsy, headache, piles, sores, toothache, nephritis, wounds, etc.

\section{Syzygium cumini Skeels.}

Common name is Jamun, is a large evergreen tree with whitish brown bark. Every year the bark is shed off. Its 
leaves are simple pointed at the tip, somewhat leathery, oval to rectangular and somewhat shiny. Flowers are mostly white and appear in cluster from axil to leaves. The fruit is berry. The fruit contains $88 \%$ moisture, $0.7 \%$ protein, $0.1 \%$ fat, $19.7 \%$ carbohydrate and $0.4 \%$ minerals. Fresh fruit had the antioxidants $708 \mathrm{mg} / 100 \mathrm{~g}$ AEAC units. The ripe fruit contains anthocyanin pigment (Rao et al., 2006). Syzygium cumini is a well known anti diabetic herb. It is a good immune modulator. It is also used in blood pressure, dysentery, diarrhoea and gingivitis.

\section{Trapaceae:}

Trapa natans or Trapa bispinosa Roxb.

It is commonly called as 'Water Chestnut'. It is annual floating aquatic plant found in fresh water, wetlands, lake, ponds and sluggish reaches of rivers in India. It has flexuose stem ascending in water, the submerged parts are furnished with numerous opposite pairs of green root-like spreading pectinate organs. Leaves are alternate, crowded on the upper parts of the stem, flowers are few, auxiliary, solitary, pure white. Fruits obovoid, angular, 2-2.5 cm long and broad, with a spreading flattened very sharp spinous horn at either side. Fruit is commonly known as 'Paniphal'. Trapa natans is a small herb well known for its medicinal properties. It is important plant of Ayurvedic system of medicine which is used in the problems of stomach, genitourinary, liver, kidney and spleen. It is bitter astringent, stomachic, diuretic and antiseptic. The whole plant is used in gonorrhoea, menorrhagia and other genital affections. It is also useful in diarrhoea, dysentery, ulcers and wounds. This is used in the validated conditions in pitta burning sensations, dipsia, dyspepsia, hemorrhage, intermittent fever, leprosy, fatigue, inflammation, fractures, bronchitis and stomach and heart burning. Its potent medicinal properties are due to the presence of phyto-chemical contents having high quantity of minerals, ions namely $\mathrm{Ca}, \mathrm{K}, \mathrm{Na}, \mathrm{Zn}$ and many Vitamins, saponins, phenols, alkaloids, H-donation, flavonoids etc. Fruit and fresh nuts have considerable content of citric acid, protein, carbohydrate, fat, dietary fibre and water (Prafulla et al., 2014).

\section{Passifloraceae:}

\section{Passiflora foetida Linn.}

A slender, foetid climbing herb with simple tendril.
Leaves ovate, marginglandular hairy. Flowers white, axillary. Fruits globose. Frequent climbing on bushes along road-sides, railway tracks, forest margins and river banks, Phenology August-December. Young leaves are used as vegetable. Passiflora foetida has been descrived as a passion flower and has been used in treatment of some diseases like as anxiety, insomnia, convulsion, sexual dysfunction, cough and cancer (Patil et al., 2013) All the leaves, flower and fruits are being used in preparation of the medicines. This species can be helpful in treating digestive problems, including dyspepsia and diarrhea. It is used in itchy skin. The decoction from the leaves and fruits of this plant is used to treat asthma, biliousness and hysteria. The leaf paste is applied for headache and to treat skin diseases.

\section{Sapotaceae:}

Madhuca latifolia Roxb.

Common name Mahua, Madhuca is a large deciduous tree reaching a height up to $20 \mathrm{~m}$. Leaves are large and broadly elliptic $12-20 \mathrm{~cm}$ long. The bark is $1.2 \mathrm{~cm}$ thick. Flowers white to cream colour with tubular, fleshy and juicy corolla. Fruit berry, ovoid, green at maturity and turn pinkish yellow when ripe. The Madhuca contains protein, carbohydrate, fat, minerals, calcium, phosphorus, iron, carotenes, sugar, Vitamins and many other nutrimental chemical constituents. The bark of Madhuca is used to cure leprosy and to heal wound, flower decoction is used for headache due to cough and cold. Paste of fresh bark is useful on joint and muscles pain. Whole plant decoction is taken orally which is useful in joint and muscles pain.

\section{Ebenaceae:}

\section{Diospyros cordifolia}

It is commonly known as Tendu is of great use for human beings. It is a large shrub or small tree. Leaves ovate-oblong, ovate lanceolate, acute, base cordate or rounded and hirsute on both surface. Flowers pale white in axillary cymes. Fruits globose yellow at maturity. It has commercial value being used in 'Bidi' industry as a raw material. Leaves are being used in stupefying fishes. It is being used in several ailments either as a cure for the well being, viz. used for lever disorders, whooping cough, leprosy, ulcers, gonorrhoea, fever as emetic and anthelmintiic. Alcoholic extract are anti inflammatory, antipyretic and analgesic. It is depressant, spasmolytic 
producing bradycardia and hypotension. Aqueous extract is being used in critical jaundicised condition. The fruits are consumed because of its juicy and sweet nature by local inhabitants (Mall, 2016).

\section{Apocynaceae:}

\section{Carrisa carandas Linn.}

Common name Karonda. Karonda is an evergreen thorny shrub. It produces sub acidic fruit rich in Vitamin $\mathrm{C}$ and minerals. Fruits contain protein, carbohydrate, fat, minerals, fibre and calcium, phosphorus, iron, $C$. carandas have astringent properties, fruit is used to expel intestinal worms, it has anti-microbial and antifungal properties, fruits also used as analgesic and anti-inflammatory. The juice of fruit can applied to relieve any skin problem. Traditionally Karonda has been used to treat anorexia and insanity.

\section{$\underline{\text { Lamiaceae }}$}

\section{Callicarpa macrophylla Syn. Callicarpa meana Roxb.}

It is commonly known as 'Beauty Berry' or 'Perfumed Cherry Tree' etc. It is a erect shrub, leaves ovate, lanceolate, elliptic, acuminate, stellate, cottony, flowers pink in dense axillary, dichotomous cymes. Fruits are 2$2.5 \mathrm{~mm}$ in diameter drupe with spongy succulent with fleshy exocarp and a hard end endocarp, single seeded. It is found frequent as shrub undergrowth in forests of Sub-Himalayan tracts. Beauty berry is a beautiful nutrimental, potent ethno medicinal plant and all the parts of the plant viz., root, bark, leaves, flower fruits and seeds are used in managements of various ailments e g. Stomach disorders, arthritis, mouth and tongue sores, burning sensation, tumor, abdominal pain, cuts, ulcers, colic diarrhoea, diabetes, stomatitis, conjunctivitis and skin ailments (Mall and Tripathi, 2015).

\section{Euphorbiaceae:}

\section{Bridelia stipularis $\mathrm{BI}$.}

Bridelia stipularis is a large more or less scendent evergreen shrub. Leaves $5-20 \mathrm{~cm}$, subcoracious, ellipticobovate or orbicular-oblong. Flowers small, in small axillary cluster or long spikes, often subtended by long stipular bracts. Fruits oblong, $12 \mathrm{~mm}$ long, seated on the enlarged calyx. Plant is used in pleurisy and exudation, bark decoction is given to children for cough, fever and asthma and a gargle for sores in mouth. Fresh tender leaves are used for the treatment of jaundice, emulsion for anaemia due to pregnancy. Leaf powder and warm leaf poultice are applied to white spots on the skin. Many phytochemicals, proteins, carbohydrate, Vitamins, alkaloids, flavenoids, steroids, phenolic substances, are reported.

\section{Moraceae:}

\section{Artocarpus heterophyllus J.R. \& G.}

Commonly known as Katahal, in English Jackfruit. It is grown in home gardens. Jackfruit is evergreen deciduous medium sized tree. Tree bark grayish black peeling off irregular chips, laticiferous, leaves $10-20 \mathrm{~cm}$, elliptic or obovate, entire, cuspidate, glabrous, dark green and glossy above, paler beneath. Flowers at first enclosed within two very, leathery stipules usually on special branchlets from trunk. Seeds $2-3 \mathrm{~cm}$ oblong, enclosed in the enlarged, flesh perianth. Ripe fruit contains high levels of carbohydrate, proteins, starch, minerals like calcium, iron, sodium, zinc, Vitamins, flavonoids, phenolic contents and other essential nutrients. Jackfruit has diverse medicinal uses especially anti-oxidant, anti-inflammatory, antimicrobial, anti-microbial, anti-cancer and anti-fungal activities (Vazhacharickal et al., 2015).

Ficus heterophylla Linn. F. Synonyms: F. Semicordata Buch. Ham. ex, F. conglomerate Roxb. Common name Laaksha-vriksha, Chorka-patra.

An erect straggling, creeping or climbing shrub. Leaves ovate, polymorphus, lanceolate or orbicular ovate, acute, base rounded or sub cordate, Receptacles 1-2 in diameter, pedunculate, solitary axillary, spherical or pyriform warted and whitish when young smooth, dark, orange when ripe. Bark decoction is used for washing ulcers, juice and powdered bark applied to wounds and bruises. Fruits are spasmolytic. Root used for bladder and visceral troubles.

Ficus recemosa Linn. Synonym: $\boldsymbol{F}$. glomerata Roxb.

Common name Gular, Gular fig, Cluster fig tree, Goolar. It is big evergreen deciduous tree. Its leaves are ovate, ovate- lanceolate or elliptic, sub acute, entire and petiolate. The plant is propagated by using cuttings of stem and root shakers or by seeds also. The flowers are pollinated by very small wasps. 


\section{Traditional uses}

Traditionally it is used in Indian medicinal practice as astringent, carminative, stomachic, vermicide etc. The extract of fruit is used in leprosy, diarrhoea, menorrhagia. It is useful in the treatment of leucorrhoea, blood disorder, burning sensation, fatigue, urinary discharge, intestinal worms and as carminative. Leaves are astringent to bowels and good in case of bronchitis, leaves are used in dysentery young tender leaves are used for fair complexion. The decoction of leaves is used to wash the wounds and ulcers. Bar is useful in asthma and piles. The latex or milky juice is administered in chronic infected wounds, haemorrhoids, boils, traumatic swelling, toothache, vaginal disorder, wounds it promote healing very soon. The root sap is used for treating diabetes (Shiksharthi and Mittal, 2011).

\section{Phytochemical properties}

The leaf of this plant contains sterols, triterpenoides (lanosterol) and alkaloids, tannins and flavonoids. Stem bark gives gluanol acetate, $\beta$-sterol, lupenol, stigmasterol. Fruit contains gluanol acetate, glucose, tiglic acid, esters of taraxasterol, lupeol acetate and other phytosterols.

\section{Morus alba Linn.}

Commonly known as 'Shahtut'. In English 'Mulberry Tree'. It is a small, deciduous tree, bark rough, grayishbrown, blaze greenish yellow with milky latex. Leaves alternate, ovate, dentate, often lobed, acuminate, base cordateor truncate. Flowers greenish, monoecious on short ovoid spikes, male spike catkin like, female spikes ovoid, purplish black at maturity. This is very common plant throughout near the villages and along the road sides. The plant of Mulberry is of multi functional as we know that it is home for silk warm, leaves are used as feed for livestock and fruit have been made into a variety of food products, cosmetics and medicines. Due to the presence of flavonoids as a major constituent Mulberry leaves possess various biological activities including anti-oxidant, antimicrobial, skin-whitening, anti-diabetic, anti-obesity, cardio-protective. Fruits are rich in Anthocyanins, and Alkaloids so have pharmacological properties such as anti-oxidant, antidiabetic, anti anaemic, hepato-proctective and immunomodulator. The root bark contains flavonoids, alkaloids and silbenoids which have antimicrobial, skin whitening and anti-inflammatory properties.
The perusal of enumeration reveals that out of 1027 plant species representing 600 genera of 134 families found in the Flora of Bahraich eighteen families were found to be represented by twenty six genera of twenty nine plant species with wild fruits of utility. Moraceae was found to be represented by three genera and four species where as Rutaceae with three genera and species each. Anacardiaceae, Caesalpinaceae, Myrtaceae and Sapotaceae with two genera and two species each. Capparidaceae, Flacourtiaceae, Bombacaceae, Averrhoaceae, Rahmnaceae, Trapaceae, Passifloraceae, Ebenaceae, Verbinaceae and Euphorbiaceae with single genera and species each. Combretaceae and Apocyanaceae were represented by single genera and two species each. The genus Terminalia, Carrisa and Ficus were represented by two species each.

Plants have always played a key role in treatment of different ailments both for human and animals all over the world. In developing countries more researchers are working on plant and plant products so the recognition of natural products is growing. Herbal medicine is an important part of both traditional and modern system of medicine. Medicinal plants being used in herbalism form the easily available source of healthcare purposes in rural and tribal areas. The wild plants growing in different stress conditions produces more potent secondary metabolites being used to cure several ailments either alone or in combination of two, three or even more plant products. Most of these wild plants are widely distributed. Many Indian plants have been used from time immemorial to treat various diseases and infections in traditional medicinal system.

Terminalia chebula is one of the most commonly used plant in traditional system of medicine in Indian subcontinent. It is called as the "King of Medicine" and is always listed at the top of the list in Ayurvedic Materia Medica due to its extra ordinary power of healing (Rathinamoorthy and Thilagavathi, 2014). It has antioxidant and free radical scavenging activities. Psidium guajava a well known popular fruit among poors contains important phytoconstituents such as tannins, triterpenes, flavonoids, triterpenoids etc is an important crop and medicinal plants available in tropical and sub-tropical climates, widely used in food and folk medicines around the world. Trapa bispinosa a poor man food contains a great quantity of nonnutritional antioxidants, such as flavonoids, flavones and total phenol contents. Jack fruit has diverse medicinal uses. Jack fruit is considered to be 
underutilized fruit where most of the fruits get wasted due to ignorance, lack of post harvest technology and gaps in supply chain system. Bombax ceiba - the samel a large deciduous tree is called as "Silent Doctor" because of its multipurpose ethnomedicinal uses. The over view of the utility of wild fruits as food and ethnomedicinal uses shows the need of awareness to the people so that they may consume when and where available and required.

\section{Conflict of interest statement}

Authors declare that they have no conflict of interest.

\section{Acknowledgement}

The authors are grateful to the local inhabitants who very kindly helped for documentation in one way or the other. Thanks are also due to The Principal, Kisan P. G. College, Bahraich, for facilities.

\section{References}

Chauhan, B. M., Duhan, A., Bhat, C. M., 1986. Nutritional value of Ker (Capparis deciduas) fruit. J. Food Sci. Technol. 23(2), 106-108.

Chin, W.Y., 2005. Plants That Heal, Thrill and Kill SNP International, Singapore 172p.

Duthie, J. F., 1994. Flora of Upper Gangetic Plain and of the Adjacent Shivalic and Sub Himalayan Tract. Botanical Survey of India, Calcutta (Reprinted).

Gautam, S., 2012. Bauhinia variegata Linn.: All purpose utility and Medicinal Tree. Forestry Bull. 12(2), 61-64.

Ghani, A., 2003. Medicinal Plants of Bangladesh with Chemical Constituents and Uses. $2^{\text {nd }}$ Edn. Asiatic Society of Bangladesh, Nimtali, Dhaka, Bangladesh.

Gopalan, C., Ramshashtri, B.V., Balasubrammaniam, S.C., 1984. Report of National Institute of Nutrition, Hyderabad, India.

Goyal, M., Sasmal, D., Nagori, B. P., 2012. Review on ethnomedicinal uses, pharmacological activity and phytochemical constituents of Ziziphus mauritiana (Z. jujuba Lam., non Mill). Spatula DD 2(2), 107116.

Hooker, J. D., 1872-1897. Flora of British India 7 Volumes, Reev and Co. Ltd., England.

Jain, V., Verma, S. K., 2014. Assessment of credibility of some folk medicinal claims on Bombax ceiba Linn. Ind. J. Trad. Knowl. 13(1), 87-94.

Jain, S.K., Rao, R.R., 1976. A Handbook of Field and
Herbarium Method. Today and Tomorrow Printers and Publishers, New Delhi.

Mall, T. P., Tripathi, S. C., 2015. Beauty Berry - A nutraceutical potent ethnomedicinal plant from North Western Tarai Forests of (UP) India, Eur. J. Biomed. Pharmaceut. Sci. 2(5), 639-645.

Mall, T.P., 2016. Diospyros cordifoia Roxb.- An under exploited potent ethnomedicinal feed- A review World J. Pharmaceut. Res. 5(8), 172-177.

Manda, H., Vyas, K., Pandya, A., Singhal, G., 2012. A complete review on Averrhoa carambola. World J. Pharmaceut. Sci. 1(1), 17-33.

Mehar, B., Dash, D. K., Roy, A., 2014. A review on: Phytochemistry, pharmacology and traditional uses of Tamarindus indica L. World J. Pharm. Pharmaceut. Sci. 3(10), 220-224.

Patil, A.S., Paikrao, H.M., Patil, S.R., 2013. Passiflora foetida Linn.: A complete morphological and phytopharmacological review. Int. J. Pharm. BioSci. 4(1), 285-296.

Prafull, A., Dongare, A., Ambavade, S. K., Bhaskar, V. H., 2014. Trapa bispinosa Roxb.: A review on nutritional and pharmacological aspects. Adv. Pharmacol. Sci. 2014, Article ID 959830. 13p.

Rahman, S., Parvin, R., 2014. Therapeutic potential of Aegle marmelos (L.)- An overview. Asian Pac. J. Trop. Dis. 4(1), 71-77.

Rao, V. K., Shivshankara, S., Prakas, G.S., 2006. Antioxidant properties of some underutilized fruits. National symposium on underutilized horticultural crops, IIHR, Bangalore. 54p.

Rashid, A., Anand, V. K., Serwar, J., 2008. Less known wild edible plants used by Gujjar tribes of Dirtrict Ralouri, Jammu aand Kashmir State, India. Int. J. Bot. 4, 219-224.

Rathinamoorthy, R., Thilagavathi, G., 2014. Terminalia chebula- Review on pharmacological and biochemical studies. Int. J. PharmTech Res. 6(1), 97-116.

Saraswathi, M.N., Karthikeyan, M., Kannan, M., Rajasekar, S., 2012. Terminalia belerica Roxb.-A phytomarcological review. Int. J. Res. Pharmaceut. Biomed. Sci. 3(1), 96-99.

Shiksharthi, A.R., Mittal, S., 2011. Ficus racemosa: Phytochemistry, traditional uses and pharmocological properties: A review. Int. J. Recent Adv. Pharmaceut. Res. 4, 6-15.

Shruthi, S. D., Roshan, A., Timilsina, S.S., Sajjekhan, S., 2013. A review on the medicinal plant Psidium guajava Linn. (Myrtaceae). J. Drug Deliv. Therapeut. 3(2), 162-168. 
Singh, J., Singh, B., Chauhan, P.S., 2013. Some useful fruit plants of wild ecosphere of Jhalawar (Rajasthan), India. Plant Arch. 13(1), 573-578.

Singh, J., 2011. Sehat ke liya phal khayein, Phal-phool, Jan-Feb, ICAR, New Delhi. pp.17-20.

Vazhacharickal, P. J., Sajeshkumar, N.K., Mathew, J.J., Kuriakose, A. C., Abraham, B., Mathew, R.J., Albin, A.N., Thomson, D., Thomas, R. S., Varghese, N., Jose, S., 2015. Chemistry and medicinal properties of jackfruit (Artocarpus heterophyllus): A review on current status of knowledge. Int. J. Innov. Res. Rev. 3(2), 83-95.

Yusuf, M., Begum, J., Haque, M. N., Chowdhary, J. D., 2009. Medicinal Plants of Bangladesh. Bangladesh Council of Scientific and Industrial Research. pp.462-463.

Zia-ul-Haq, M., Gavar, S., Qayam, M., Imran, I., de Feo, V., 2011. Compositional studies: Antioxidant and antidiabetic activities of Capparis decidua (Forsk.) Edgew. Int. J. Mol. Sci. 12(12), 8846-8861.

http://www.medicalnewstoday.com/article/283476.php

http://www.medicinalnewstoday.com/article/283476php

\section{How to cite this article:}

Mall, T. P., Tripathi, S. C., 2017. Diversity of wild nutrimental fruits of District Bahraich, Uttar Pradesh, India. Int. J.

Curr. Res. Biosci. Plant Biol. 4(1), 65-76. doi: http://dx.doi.org/10.20546/ijcrbp.2017.401.008 